\title{
Domestic violence: legal aspect of the problem
}

\author{
Marina Aleksandrovna Buchakova ${ }^{1^{*}}$, Evgeniy Viktorovich Koshelev ${ }^{1}$, Liliya Mudarisovna \\ Altynbaeva $^{1}$, Andrey Aleksandrovich Gaydukov ${ }^{2}$, and Aleksandr Ivanovich Scheglov ${ }^{2}$ \\ ${ }^{1}$ Omsk Academy of the Ministry of Internal Affairs of the Russian Federation, Department of \\ Constitutional and International Law, Omsk, Russia \\ ${ }^{2}$ Barnaul Law Institute of the Ministry of Internal Affairs of the Russian Federation, Department of \\ Administrative Law and Administrative Activity of Internal Affairs Agencies, Barnaul, Russia
}

\begin{abstract}
Prerequisites of research. The authors of the article study the approaches to the solution of the domestic violence problem from the position of different branches of law: constitutional, international, family, administrative, and criminal law that allows revealing the inconsistence and collisions in the current legislation related to this phenomenon. Objectives of the research. The objective of the research is to analyze the legal aspects of the problem related to domestic violence and also search for possible ways of their solution directed to the improvement of the current criminal and administrative legislation. Methods. The following system of methods was used in the research: analysis, synthesis, and the system approach. In addition, the comparative and legal methods were applied when analyzing the international norms and individual laws of the foreign states directed to combatting domestic violence. Results. The improvement of legal regulation in regard to the establishment of consistency of branches of law, first of all, administrative and criminal legislation. Basing upon the current norms of criminal, administrative, and family legislation, the conclusions are made of the consistency, wrongfulness, and public danger of domestic violence, the main form of which in Russia is physical abuse of the people having family and domestic relations with a law-breaker. Domestic violence is a complex social phenomenon. It appears depending upon the object of abuse and its consequences, as a rule, are spread to all family members. The violence acts are made mainly to women and have a latent character. Only the legally punishable acts provided by the legislation of administrative violations and criminal law can be considered the expression of domestic violence. Novelty. A complex interbranch approach to the domestic violence problem is used, the suggestions for the improvement of the current legislation are offered.
\end{abstract}

Keywords: family and domestic violence, domestic violence, combatting, aggression

* Corresponding author: mb290163@mail.ru 


\section{Introduction}

Domestic violence is one of the most complicated and problematic topics falling within the scope of interests of various legal sciences (constitutional, international, family, administrative, criminal law), besides, it is the object of study of philosophy, psychology, sociology, and pedagogics. The complicated character of the studied problematics is, as a rule, in the latency of this offense. Thus, people suffering from domestic violence try to hide these facts, do not report them to the corresponding law enforcement agencies and therefore they contribute to the formation of conditions when an abuser feels his impunity and continues to abuse his loved one with various violent actions.

According to the official data of the Main Information and Analysis Center of the Ministry of Internal Affairs of the Russian Federation, 237,727 crimes were registered in the family and domestic field, including 54,285 crimes in 2015; 63,535 crimes in 2016; 38,311 crimes in 2017; 34,195 crimes in 2018; 31,942 crimes in 2019; and 15,459 crimes [1] for the six months of 2020. Despite the decrease in the total number of crimes committed in the family and domestic field, the number of applications from women to the anti-crisis centers increased confirming the importance of the studied problematics.

\subsection{Review of the theoretical background of the research}

Foreign and Russian thinkers, philosophers studied violence as a social problem and its variety in society. Philosophical and sociological aspects of violence in the 19th-20th centuries were studied in the works by Pareto [2], Sorel, [3] Arendt [4], Jaspers [5], etc.

In Russia, the problem of violence was considered in the works by Leo Tolstoy, who offered the theory of nonresistance to evil by violence. In the opinion of the great writer, "one of the reasons of people's miseries is a wrong idea that some people can improve or change the life of other people with violence" [6, p. 199]. The phenomenon of violence was also studied in the works of the famous Russian philosopher Berdyaev, in whose opinion the problem is violence and attitude towards it is too complicated for understanding. The thinker believed that "psychological abuse plays a more important role in life than physical abuse. A person loses his freedom and becomes a slave not only by physical abuse. The social infusion felt by the person from his childhood can make him a slave. The educational system can deprive the freedom of a person completely and make him incapable to judge freely" [7]. The famous Russian philosopher Huseynov points out that violence is the usurpation of free will [8].

In Russian law, the problems of domestic violence were raised in the works of criminologists such as Arakelyan [9], Kim [10], Kotsyuba [11], etc. The problem of domestic violence was considered by them through the prism of reasons and conditions of crime commitment, the personality of a criminal, and a mechanism of his illegal behavior. The questions of administrative liability and prevention of violations of law in the family were developed as a part of the administrative activity of police in the studies by Gaydukov [12] and Ravnyushkin [13].

The theoretical and legal aspect of the problem is the absence of a legal notion of "domestic violence" in Russian law and that leads to the use of the conceptual apparatus having a different meaning: "family violence", "domestic violence", etc. In its turn, it will allow not only raising the question about the group of subjects being the participants in this offense but also determining the body of particular offenses. 


\subsection{Rationale for the novelty of the research}

When investigating the problem of domestic violence, the authors use a complex interbranch approach to this problem, which is expressed in the fact that people that abuse their loved ones should bear legal responsibility that presupposes the consistency of norms of criminal and administrative legislation.

\subsection{Hypothesis}

Domestic violence is a social problem that remains regardless of the existing state structure and legal system. It is necessary to combat it using a complex of measures, among which the legal measures are the main ones.

\subsection{Objective}

Objective of the research is to analyze the legal aspects of the problem related to domestic violence and also to determine the possible ways of their solving. The achievement of the set objective predetermined the necessity to solve the following tasks: to analyze the norms of international law, statutes, and regulations of the foreign countries, as well as the national legislation, and basing on it, to formulate the suggestions for further improvement of the norms of the Russian law in the field under study.

\section{Methods}

First of all, the work used the formal and legal method for the analysis of the current legislation, analysis, synthesis, the system approach, as well as the comparative legal method.

\section{Discussion}

The availability of a significant number of international documents dedicated to the questions of domestic violence, its counteractions are the confirmation of the importance of the studied problematics in the modern world. Thus, the analysis of the international agreements directed to the protection of the family allowed revealing various legal aspects related to the notion of "domestic violence". In the Declaration on the Elimination of Violence Against Women accepted by the Resolution 48/104 of the United Nations General Assembly on December 20,1993 , domestic violence is determined as a part of wrongful acts against women. Its main forms are physical, sexual, and psychological violence [14].

The Convention of the Council of Europe on Preventing and Combating Violence Against Women and Domestic Violence (CETS N 210) [15] not only specified the forms of domestic violence that include the acts of physical, sexual, psychological, or economic violence but also determined a group of participants in family relations which includes the members of the family or housemates or ex-spouses or current spouses or partners regardless the place of joint residence.

In the resolution of the European Court of Human Rights on July 09, 20019 on domestic violence in Russia "Volodina versus the Russian Federation", it is declared that domestic violence can have various forms from physical beatings to sexual, economic, emotional violence or verbal abuse [16].

The analysis of the foreign legislations shows the absence of identity in the definition of a form or content of the notion "domestic violence". Thus, in the Republic of Belarus, domestic violence is understood as "willful acts of physical, psychological, sexual nature of 
a family member to the other family member that violate his rights, freedom, legitimate interests and cause him physical and (or) mental sufferings" [17].

In Article 2 of the law of the People's Republic of China "On Combatting Domestic Violence", domestic violence is understood as battery, maiming, restraining, personal restraint, everyday abuse, threat, and other actions causing physical and mental harm [18].

The law of the Kyrgyz Republic explains domestic violence as willful acts of physical, psychological, economic nature or their threat, as well as disrespect committed by one family member, a person equal to him, to the other family member, a person equal to him [19].

In the authors' opinion, the legislation of Georgia seems interesting that was on the way of criminalization of domestic violence and separated the liability for family crimes. In Georgia, the acts of domestic violence were concretized and a criminal and his family members were recognized as special subjects [20].

The Constitution of the Russian Federation (P. 2 Art. 21) contains the prohibition of moral and physical abusing of someone [21]. Family law [22] and effective judicial practice [23] mention only two forms of violence: physical and mental, including child abuse and attempting to the sexual immunity of children. The order of the President of the Russian Federation No. 712 dd. May 14, 1996 "On the Main Directions of the State Family Policy" mentions domestic violence in any of its demonstrations [24].

The resolution of the Government of the Russian Federation No. 6 dd. January 08, 1996 "On the Concept of Improvement of the Status of Women in the Russian Federation" recognized various forms of violence to women in a family such as regular battery and mental abuse [25].

The National Strategy of Actions for Women Interests for 2017-2022 left unchanged the earlier mentioned forms of violence to women in a family [26].

The Concept of the State Family Policy in the Russian Federation for the period up to 2025 [27] specifies that family and domestic violence has physical and psychological forms.

\section{$4 \quad$ Results}

Studying the forms of violence in a family, the following important parameters shall be taken into account. First, demonstration of abuse depending upon the object that is spread to all people who have family and domestic relations with a law-breaker. In this regard, the list of people who are subjected to this type of relations shall be clearly determined, as well as the criteria shall be taken into account that are essential when detecting the fact of domestic violence, that is, joint household or child-raising.

Second, despite the fact that the norms of international laws draw attention to the violence in a family mainly to women and most of them point out the single demonstrations of them, in the authors' opinion, the system character of such actions in the family and the severity level of bodily injury are important.

Third, only legally punishable offenses, provided for by the legislation of administrative offenses and criminal law, will be considered the demonstration of violence in a family.

\section{Conclusion}

The system of combatting domestic violence existing in the Russian Federation requires unconditionally certain legal corrections taking into account the specific character of the family and domestic field. When qualifying the administrative offenses and crimes, the special subject should be determined, that is, a person who had family and domestic relations with an injured person. 


\section{References}

1. Statistics of the Ministry of Internal Affairs of the Russian Federation, crimes in the field of family and domestic relations are recorded since 2015, Main Information and Analysis Center of the Ministry of Internal Affairs of the Russian Federation.

2. V. Pareto, Kompendium po obshchei sotsiologii [Compendium of General Sociology] (Publishing House of the State University Higher School of Economics, 2008)

3. G. Sorel, Razmyshleniya o nasilii [Reflections on violence] (Akademicheskii proekt, Saint Petersburg, 2005)

4. H. Arendt, On Violence (Harvest, New York, 1970)

5. K. Jaspers, Philosophie. Bd. 1 (Springer-Verlag, Berlin-Heidelberg, 1973)

6. L.N. Tolstoy, Zakon nasiliya i zakon lyubvi [Law of violence and law of love], in L.N. Tolstoy, Polnoe sobranie sochinenii v 90 tt. [Complete works in 90 vols.], Vol. 37 (Khudozhestvennaya literatura, Moscow, 1956)

7. N.A. Berdyaev, O rabstve i svobode cheloveka [On slavery and freedom of a person] (Direct-Media, Moscow, 2008)

8. A.A. Huseynov, Voprosy filosofii, 6, 35-41 (1994)

9. S.V. Arakelyan, Ubiistva $v$ sfere semeino-bytovykh otnoshenii i ikh preduprezhdenie: Po materialam Respubliki Armeniya [Murders in the field of family and domestic relations and their prevention: Based on the materials of the Republic of Armenia], $\mathrm{PhD}$ thesis (Yerevan State University, Yerevan, 1999)

10. E.P. Kim, Prestupnost v sfere bytovykh otnoshenii i ee preduprezhdenie: Problemy teorii i praktiki [Criminality in the field of domestic relations and its prevention: Problems of theory and practice], PhD thesis (Law Institute of the Ministry of Internal Affairs of Russia, Moscow, 2002)

11. V.A. Kotsyuba, Kriminologicheskii analiz i preduprezhdenie prestuplenii v sfere semeino-bytovykh otnoshenii: Po materialam Dalnevostochnogo regiona [Criminological analysis and prevention of crimes in the field of family and domestic relations: Based on the materials of the Far Eastern region], Abstract of a PhD thesis (Far East Law Institute of the Ministry of Internal Affairs of Russia, Krasnoyarsk, 2004)

12. A.A. Gaydukov, Administrativno-pravovoe regulirovanie deyatelnosti politsii po preduprezhdeniyu i presecheniyu pravonarushenii v sfere semeino-bytovykh otnoshenii [Administrative and legal regulation of police activity in prevention and repression of offences in the field of family and domestic relations], PhD thesis (Omsk Academy of the Ministry of Internal Affairs of Russia, Omsk, 2018)

13. A.V. Ravnyushkin, Administrativno-pravovye sredstva preduprezhdeniya i presecheniya organami vnutrennikh del pravonarushenii v sfere semeino-bytovykh otnoshenii [Administrative and legal means of prevention and repression of offences in the field of family and domestic relations by law enforcement agencies], $\mathrm{PhD}$ thesis Abstract (Academy of Management of the Ministry of Internal Affairs of Russia, Moscow, 2015)

14. UN Declaration on the Elimination of Violence against Women (1993, December 20). Accessed on: March 19, 2021. [Online]. Available: http://www.un.org/ru/documents/decl_conv/declarations/violence.shtml

15. Council of Europe Convention on Preventing and Combating Violence against Women and Domestic Violence (CETS N 210) (Istanbul, 2011, May 11). Accessed on: March 
19, 2021. [Online]. Available: https://www.coe.int/ru/web/conventions/full-list//conventions/treaty/210

16. Bulletin of the European Court of Human Rights. Russian Edition, 4 (2020)

17. Zakon Respubliki Belarus 4 yanvarya 2014 g. No. 122-Z "Ob osnovakh deyatelnosti po profilaktike pravonarushenii" [Law of the Republic of Belarus No. 122-Z "On Fundamental Principles of Crime Prevention Activity"] (2014, January 4). Accessed on: March 19, 2021. [Online]. Available:

https://pravo.by/upload/docs/op/H11400122_1389733200.pdf

18. Zakon Kitaiskoi Narodnoi Respubliki “O borbe s domashnim nasiliem" [Law of the People's Republic of China "On Combatting Domestic Violence"] (2016). Accepted at the $18^{\text {th }}$ Session of the Standing Committee of the $12^{\text {th }}$ Chinese National People's Congress

19. Zakon Kyrgyzskoi Respubliki ot 27 aprelya 2017 g. No. 63 "Ob okhrane i zashchite ot semeinogo nasiliya" [Law of the Kyrgyz Republic No. 63 "On Protection and Defence from Domestic Violence"] (2017, April 27). Accessed on: March 19, 2021. [Online]. Available: http://cbd.minjust.gov.kg/act/view/ru-ru/111570

20. Ugolovnyi kodeks Gruzii [Criminal Code of Georgia] (2019). Accessed on: March 19, 2021. [Online].

Available: https://matsne.gov.ge/ka/document/download/16426/143/ru/pdf

21. G.D. Sadovnikova, Kommentarii k Konstitutsii RF postateinyi [Article-by-article comment to the Constitution of the Russian Federation] (Urait, Moscow, 2019)

22. Semeinyi kodeks Rossiiskoi Federatsii ot 29 dekabrya 1995 g. No. 223-FZ [Family Code of the Russian Federation No. 223-FZ (1995, December 29)

23. Postanovlenie Plenuma Verkhovnogo Suda RF ot 14 noyabrya 2017 g. No. 44 "O praktike primeneniya sudami zakonodatelstva pri razreshenii sporov, svyazannykh s zashchitoi prav i zakonnykh interesov rebenka pri neposredstvennoi ugroze ego zhizni ili zdorovyu, a takzhe pri ogranichenii ili lishenii roditelskikh prav" [Decree No. 44 of the Plenum of Supreme Court of the Russian Federation "On practice of legislation application by the courts when settling the disputes related to the protection of rights and legitimate interests of a child in case of the direct threat to his life and health as well as in restriction or deprivation of parental rights"] (2017, November 14)

24. Ukaz Prezidenta Rossiiskoi Federatsii ot 14 maya 1996 g. No. 712 "Ob osnovnykh napravleniyakh gosudarstvennoi semeinoi politiki" [Decree of the President of the Russian Federation No. 712 "On Main Directions of the State Family Policy"] (1996, May 14)

25. Collection of Legislation of the Russian Federation, 3, Item 185 (1996)

26. Collection of Legislation of the Russian Federation, 11, Item 1618 (2017)

27. Collection of Legislation of the Russian Federation, 35, Item 4811 (2014) 